\title{
Psychological Content of the Problem on the Growth of Pupils as the Subjects of Studying Process
}

\section{Психологічний зміст проблеми формування учнів як суб'єктів учіння}

\section{Nataliia Ternovyk}

Ph. D. in Psychology, Assistant Professor, International Economic and Humanities University named after Stepan Demianchuk, Rivne (Ukraine)

ORCID ID: https://orcid.org/0000-0002-1425-2423

Researcher ID: http://www.researcherid.com/rid/AAH-8779-2020 scopus.com

E-mail: nato4ka66@ukr.net

\section{Наталія Терновик}

Кандидат психологічних наук, доцент, Міжнародний економіко-гуманітарний університет імені академіка Степана Дем'янчука, м. Рівне (Україна)

\section{Alla Simko}

Ph.D. in Psychology, Senior Lecturer, Kamianets-Podilskyi National Ivan Ohiienko University, Kamianets-Podilskyi (Ukraine)

ORCID ID: https://orcid.org/0000-0002-6197-9086

E-mail: 7kort@ukr.net

\section{Алла Сімко}

Кандидат психологічних наук, старший викладач, Кам'янецьПодільський національний університет імені Івана Огієнка, м. Кам’янець-Подільський (Україна)

Address for correspondence, e-mail: kpnu_lab_ps@ukr.net Copyright: (C) Ternovyk Nataliia, Simko Alla

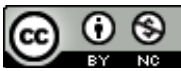

The article is licensed under CC BY-NC 4.0 International (https://creativecommons.org/licenses/by-nc/4.0/)

DOI (article): https://doi.org/10.32626/2227-6246.2021-52.253-274

(C) Ternovyk Nataliia, Simko Alla 
DOI: https://doi.org/10.32626/2227-6246.2021-52

2021. випуск 52

The author's contribution: Ternovyk N. $-50 \%$, Simko A. $-50 \%$.

Авторський внесок: Терновик Н. $-50 \%$, Сімко А. $-50 \%$.

\section{ABSTRACT}

The purpose of our research is to provide the experiment at secondary school with the aim to establish the degree of the development of pupils as Subjects of cognitive activity based on the analysis of the content of internal communication between schoolchildren and novels at different stages of understanding its content in situations of solving discursive creative tasks in a diverse literary and personal environment.

The following theoretical methods of the research were used to solve the tasks formulated in the article: a categorical method, structural and functional methods, the methods of the analysis, systematization, modeling, generalization. As the experimental method we used author's methodology "A questionnaire for schoolchildren".

The results of the research. We have to note that all levels of the Subject's positions are concentrated in one person. Also we assume that depending on pupils' activity, the individual manifests himself / herself functionally at one level or another one by his / her own subjectivity, remaining structurally at a certain level of spirituality.

Subjectivity as a tendency to reproduce, to create oneself in appropriate and sometimes unfavorable conditions, is a universal characteristic of a person. Man's own activity is qualitatively transformed at each stage of ontogenesis, its role in mental development increases at the time of mental generation. Subjectivity does not arise suddenly and is not introduced from outside, it is a genetic consequence of the transformation of lower forms into higher ones due to the self-development of the subjective principle of a person who actively interacts with the outside world. In this case, the social environment of the individual as a subject of activity plays an adequate role of external factors, conditions, but not determinants, which do not cause a mental development of the Subject.

Conclusions. Thus, the subject of mental activity can be considered as the individual if the object for him / her is his / her own psyche in its functioning and development; the regulation of the development processes is carried out by the Subject himself / herself, and not by any external forces, both on the conscious and unconscious levels (in the direction from what is not realized to what is increasingly realized with the transition of learned forms of self-regu(C) Ternovyk Nataliia, Simko Alla

DOI (article): https://doi.org/10.32626/2227-6246.2021-52.253-274 http://journals.uran.ua/index.php/2227-6246 
lation to subconscious levels). The Subject of mental activity provides individual acts only by the conditions of the development of own Subjective structures and building of the corresponding potentialities. In such a way, we think, that mature subject of mental activity will be characterized by such needs and abilities: 1) "goal-setting" of pupils' mental self-development as a regulators of this process; 2) providing "choice», "finding", "production" of psychological means which are necessary to achieve this goal; 3) "decision-making» about when and under what conditions the goal can be achieved by selected means to the maximum extent; 4) the implementation of decisions; 5) the "evaluation" of the results of implementation, the analysis of the causes of success and failure; 6) the "accumulation" of individual experience, the "fixation" of results and ways of the development of the psyche and the Subjective qualities of the person.

Key words: the Subject, subjectivity, understanding novels, a certain level of spirituality, the "evaluation" of the results of implementation, the "accumulation» of individual experience.

\section{Introduction}

The problem of the growth of pupils as the Subjects of studying is rather new in psychological literature. We'll explain this statement in such a way. Psychological ideology forced to shift the emphasis into the analyzed problem in the direction of the function of a man's activity, which appeared in the concept of this activity. This version of the activity approach emphasized the structure of the activity (its motives, different subjects, their purposes, a result), its objectivity, and the problem of the subject became on the secondary place. The activity gradually turned into a self-sufficient, capable process of developing as the independent category.

Over time, the concept of Subject has been differentiated. For example, researchers distinguished between the Subject of cognition, the Subject of the activity, the Subject of communication (Adler, Lindzey \& Hall, 1997). Nowadays this differentiation became even more noticeable: it was appeared as the Subject of morality, the Subject of mental activity, the Subject of Ethics, the Subject of joint activity, the Society as a Subject,

C Ternovyk Nataliia, Simko Alla

DOI (article): https://doi.org/10.32626/2227-6246.2021-52.253-274 
DOI: https://doi.org/10.32626/2227-6246.2021-52

2021. випУСК 52

the Subject of education, upbringing of children. Common to these concepts was the methodological recognition of human activity and an indication of their differences. The dynamics of the historical process intensified a great need for further theoretical and methodological development of the problem of the Subject as an integral characteristic. In addition, it can be the basis for the convergence of a number of areas in Psychology (Onufriieva, Chaikovska, Kobets, Pavelkiv \& Melnychuk, 2020).

Today, in the psychological and philosophical literature everyone can find different definitions of the concept of «Subject»: from essentially identical to exactly opposite ones.

The philosophical understanding provides a definition according to which the Subject is a delineation of the theoreticalcognitive «Me», which is opposed to "Non-Me», or the designation of the individual, which directs to the object to which he / she opposes, opposes his / her knowledge as the «Object of cognition» or the certain action («The Subject of the action») (Brédart, 1991). In our opinion, although in this definition the individual is endowed with a certain activity, it is not clear who opposes the object and the subject.

According to researchers, the Subject is the carrier of the subjective, externally objectified. The authors note that this is not only a man, but also any animal capable of mental reflection (Abrams \& Hogg, 1999). Thus, it is not the individual or the animal that acts as a Subject, but their psyche, which, by absorbing individuals, animals as material, possesses them. But, as some researchers note, the Subject is not the human psyche, but the person who possesses the psyche, not its certain mental characteristics, but the person who acts, communicates, etc. (Dubovyk, Mytnyk, Mykhalchuk, Ivashkevych \& Khupavtseva, 2020). These researchers convinced that Subjects could be only people, not animals and not machines. The scientists call the most important quality of a person the ability to be a Subject, such as the creator of his / her life. Man as a subject initially (C) Ternovyk Nataliia, Simko Alla

DOI (article): https://doi.org/10.32626/2227-6246.2021-52.253-274 
DOI: https://doi.org/10.32626/2227-6246.2021-52

2021. випуСК 52

initiates and carries out practical activities, communication, behavior, cognition and other types of the activities (Vovk, Emishyants, Zelenko, Drobot \& Onufriieva, 2020).

In other researches (Bennett, 1998; Mykhalchuk \& Kryshevych, 2019) we find that the Subject is an individual or a group of people as a source of knowledge and transformation of reality; the carrier of the activity, which makes a change in other people and in himself / herself as another one. The Subjectivity of a person is manifested in his / her vitality, in the activity, communication, self-awareness (Beauvillain, 1994). In this source, the Subject is understood as a purposeful, integral, free being that develops himself / herself.

Let us show the relationship between the concepts of «individual», «Subject», «Personality», «Individuality». All of these concepts are interrelated, but not identical. Each of them means a certain, qualitatively new stage of the development of a human psyche. In terms of genesis, we would place them in such a way: an individual, a Subject, a Personality, an Individuality. Because, as R. Descartes noted, nothing is more obvious than a figure, because it can be perceived and it was seen.

Let's show schematically the relationship of these concepts. First of all, let's try to describe the understanding of this issue, finding the terminology of formal logic. Let us denote by A, B, C, D some sets, the elements of which are the qualities of the individual, the Subject, the Personality, the Individuality. Then the relationships between these sets can be described as belonging the set $A$ to the set $B(A \subset B)$, the set $B$ to the set $C(B \subset C)$, the set $C$ to the set $D(C \subset D)$. Then, $A$ $\subset \mathrm{B} \subset \mathrm{C} \subset \mathrm{D}$ (Fig. 1).

Structurally, Subjectivity occurs both at the Personal stage and at the level of the Individuality. That is, when we talk, for example, about the Individuality, we take into account the bodily existence of a man (as the Individual), his / her attitude to the activity (as a Subject) and his / her social existence (as a Person).

(C) Ternovyk Nataliia, Simko Alla

DOI (article): https://doi.org/10.32626/2227-6246.2021-52.253-274 


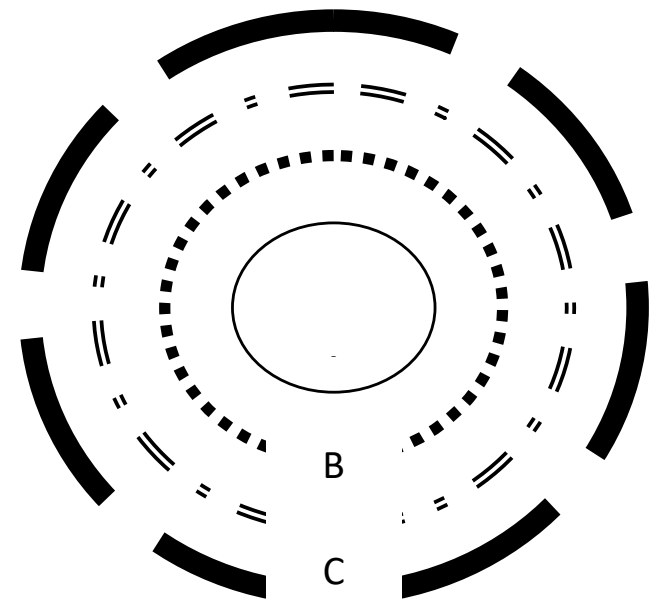

Fig. 1. The Subjective structure of a man

Symbols: A is an individual; B is a Subject; C is a Personality; $\mathrm{D}$ is an Individuality.

We've to note that Subjective qualities do not firstly develop, and then a function within the Individual is displayed at the postpersonal-individual level of the genesis of the psyche, but it is developed by functioning at these levels.

The purpose of our research is to provide the experiment at secondary school with the aim to establish the degree of the development of pupils as Subjects of cognitive activity based on the analysis of the content of internal communication between schoolchildren and novels at different stages of understanding its content in situations of solving discursive creative tasks in a diverse literary and personal environment.

\section{Methods of the research}

The following theoretical methods of the research were used to solve the tasks formulated in the article: a categorical method, structural and functional methods, the methods of the analysis, systematization, modeling, generalization. As the C Ternovyk Nataliia, Simko Alla

DOI (article): https://doi.org/10.32626/2227-6246.2021-52.253-274 
experimental method we used author's methodology «A questionnaire for schoolchildren».

\section{Results and their discussion}

To get to know the state of the formation of Subjectivity of adolescent we provided the experiment. The experiment was conducted from 2019 to 2020. Its purpose was to establish the degree of the development of pupils as Subjects of cognitive activity based on the analysis of the content of internal communication between schoolchildren and novels at different stages of understanding its content in situations of solving discursive creative tasks in a diverse literary and personal environment (we organized our experiment at the lessons of Foreign Literature).

We formed experimental and control groups by random method (125 adolescents):

\section{- experimental groups:}

E1 (35 pupils) - 8-B form of secondary school № 12 (city of Rivne).

E2 (25 pupils) - 7-A form of Gorokhiv Secondary School № 1 (Rivne region);

\section{- control groups:}

C1 (35 pupils) - 8-A form of secondary school № 12 (city of Rivne).

C2 (30 pupils) - 7-B form of Gorokhiv Secondary School № 1 (Rivne region).

At the first stage, the questionnaire method was used. We proposed our author's questionnaire for pupils.

\section{A questionnaire for schoolchildren}

1. Do you like to read novels?

2. How many novels did you read last year?

3. Who do you discuss novels with?

4. Do you always understand the novel you have read?

5. What novels do you like most of all (classic, detective, fiction, others)? 
DOI: https://doi.org/10.32626/2227-6246.2021-52

2021. випуск 52

6 . What novels do your parents like and why?

7. Do you love and understand classical literature? If not, explain.

8. If you were the author of a novel, what would you tell in it?

9. What can a novel tell better than music, painting?

10. What do you think about when reading a novel?

11. Why do you think the author of the novel wants his / her text to be read by people?

12. What novels would you like to read and discuss in class?

The content of the questionnaire has the aim of studying the qualitative characteristics of the literary environment of adolescents: the number of novels read by pupils last year, the complexity and diversity of the latter, the means of assigning literary culture, the degree of self-awareness (the last two points appear as reflexive moments). Accordingly, the data obtained from the survey allowed:

a) to state the number of novels read by pupils the last year;

b) to identify reference of different persons (those people with whom pupils read novels are discussed by them);

c) to reveal the semantic side of the pupils' internal communication with a novel;

d) to establish the means of communication between pupils and the novel and to distinguish the degree of awareness of the latter.

The analysis of the answers of pupils who studied both the program with in-depth research of Foreign Literature (forms $\mathrm{E} 1, \mathrm{C} 1$ ) and the standard program (forms E2, C2), allows us to identify common to this age group of pupils characteristics of the literary environment. Thus, Foreign Literature is the subject of communication for $65 \%$ of adolescents in form $\mathrm{E} 1$, $61 \%$ - for $\mathrm{C} 1,53 \%$ - for $\mathrm{E} 2,74 \%$ - for $\mathrm{C} 2$ ). The most active is the communication of pupils on literary issues with friends (C) Ternovyk Nataliia, Simko Alla

DOI (article): https://doi.org/10.32626/2227-6246.2021-52.253-274 
and parents (respectively $56 \%$ of pupils in E1, $52 \%$ - in C2, $48 \%$ - in E2, 73\% - in C2. Teachers of Foreign Literature are real partners of communication with pupils on literary topics for $27 \%$ of schoolchildren in E1 form, $25 \%$ - in C1, 38\% - in $\mathrm{E} 2,22 \%$ - in C2. The tendency to narrow the circle of competent adults, namely teachers (compared with friends and parents), is one of the reasons for declining the level of literary development of pupils.

The semantic aspect of adolescents' communication is characterized by an imbalance of their interests in relations to different areas of literary culture. The latter is largely represented by fiction and detective fiction. This data is higher in form C2. In this control form there is a slight increase in the percentage of pupils (for the period from the 6 th to the 8th forms), who are more interested in these novels than in classical ones: $55 \%$ of pupils - in the 6 th form (C1), $77 \%$ - in the 8 th form $(\mathrm{C} 1)$. In form $\mathrm{E} 1$ the values of this indicator are respectively $38-39 \%$, in $\mathrm{E} 2-66-74 \%$, in $\mathrm{C} 2-63-68 \%$.

We determined the percentage of conversations or discussions of novels in the communication of pupils (such as the discussion of the plot of novels, about main characters, unfolding events, etc.): in the form E1 - 31\% and 32\%, in E2 - 29\% and $37 \%$, in $\mathrm{C} 1-33 \%$ and $34 \%$, in $\mathrm{C} 2-27 \%$ and $25 \%$ (data for 2019-2020, 2020-2021 academic years).

There is also a general tendency to displace literary classics from the sphere of literary interests of adolescents. This trend is confirmed by the answers of pupils to the questionnaire about their literary interests, which was asked in the indirect form ( "What novels would you like to read and discuss in the learning process?»). Answering this question, the percentage of novels is for $\mathrm{E} 1$ from the 6 th to the 8 th forms, respectively, $48 \%$ and $35 \%$, for E2 from the 6 th to the 8 th forms $-36 \%$ and $22 \%$, for $\mathrm{C} 1-30 \%$ and $29 \%$, for $\mathrm{C} 2-24 \%$ and $21 \%$. The difference in the quantitative values of these data and the data above suggestions that the motivation of «communication" of (C) Ternovyk Nataliia, Simko Alla DOI (article): https://doi.org/10.32626/2227-6246.2021-52.253-274 
DOI: https://doi.org/10.32626/2227-6246.2021-52

2021. випУСК 52

adolescents with serious literary novels is external: teenagers like classical novels more because of their personal interests and needs.

At the stage of proposing pupils the questionnaire, we tried to imagine the degree of the development of the adolescent as a subject of cognitive activity due to the influence of the literary environment, which was determined at the level of studying pupils' opinions about literature, the specifics of literary reality, means of literary culture. For this purpose, questions were used that required the choice of one of the proposed answers, as well as open-ended questions. It should be noted that the majority of pupils had difficulty answering open-ended questions. This was manifested in the teenagers' appeals to the experimenter: «I don't know», "We weren't told...». Such difficulties indicate a focus on knowledge rather than on the thinking of pupils, which generally reflects the predominant focus of schooling. This is also confirmed by the fact that the experimenter's instruction ( "In cases of difficulty in a case of answering a difficult question not to answer it immediately, but to think and to answer it later») pupils usually did not do the second part.

The formation of adolescents' ideas about the specifics of the figurative reflection of the reality in literature was determined by analyzing their answers to the questionnaire: "If you were the author of a novel, what would you tell in it?», "What can a novel tell better than music, painting?». Such questions were more difficult for pupils of forms E2, C2. Thus, the first question in the form E1 was not answered by $16 \%$ of pupils, in $\mathrm{C} 1-21 \%$, and in the form E2 - respectively $48 \%$ of adolescents, in $\mathrm{C} 2-59 \%$; the second question in the form $\mathrm{E} 1$ was not answered by $34 \%$ of pupils, in $\mathrm{C} 1$ - by $48 \%$, and in the form $\mathrm{E} 2$ - by $62 \%$ of teenagers, in $\mathrm{C} 2-68 \%$. These data emphasize the opposite trends in the understanding of pupils of forms E1, C1 and E2, C2 specifics of the literary image. This trend is confirmed by the results below.

C Ternovyk Nataliia, Simko Alla

DOI (article): https://doi.org/10.32626/2227-6246.2021-52.253-274 
Thus, the understanding of the specifics of the content of a novel as a personal experience of a man was manifested in the answers of pupils to the question posed in the indirect form: "Why do you think the author wants his / her novel to be read by people?» and it was expressed by the following values: $54 \%$ of pupils of the form E1 and 51\% - in C1, 65\% of schoolchildren in E2 and $62 \%$ of pupils of the form C2 answered that the author writes a novel especially for people, so he / she is interested in reading it; $26 \%$ of teenagers in the form $\mathrm{E} 1,34 \%$ - in $\mathrm{C} 1,18 \%$ - in $\mathrm{E} 2,17 \%$ - in $\mathrm{C} 2$ answered that the author through a novel wants to tell people a certain truth, to tell about a question or a problem that worries him / her; $16 \%$ of pupils from E1 and $29 \%$ of $\mathrm{C} 1$ believe that people who write a novel necessarily have a talent that is expressed in this form. The answers to the questionnaire allowed us to determine whether pupils are aware of contact with novels as a communicative situation. This question was answered positively by $18 \%$ of pupils in the form $\mathrm{E} 1,19 \%$ - in $\mathrm{E} 2,28 \%$ - in the form C1, 23\% - in C2. These data indicate that literature is perceived as a form of communication only by some pupils.

These questionnaires show a weak expression of adolescents' focus on another person, the penetration into his / her inner world in a situation of a real communication with other pupils and teachers. Thus, after surveying pupils, it was found that only $58 \%$ of teens in the form E1, 69\% - in E2, 43\% in $\mathrm{C} 1,46 \%$ - in $\mathrm{C} 2$ were able to name their parents' favorite novels and only a quarter of teens in each group correctly indicated the reasons for parental sympathy (this conclusion is made by comparing the responses of pupils and their parents. For parents we proposed the same questionnaire as for pupils).

Including into the questionnaire the question «What do you think when reading a novel?», we intended to find out both the general orientation of pupils to understand its content, and the nature of their thoughts. The analysis of the answers to this question allows us to talk about two tendencies

(C) Ternovyk Nataliia, Simko Alla DOI (article): https://doi.org/10.32626/2227-6246.2021-52.253-274 
DOI: https://doi.org/10.32626/2227-6246.2021-52

2021. випуск 52

in the communication of adolescents with literature - «the adequate one» and "the inadequate tendency». The first characterizes the focus of pupils on understanding the content of a novel and it was represented by the answers: "I think about what the author says in the novel», "I try to understand the content of the novel», "I imagine the pictures having been told in the novel», etc.

An inadequate tendency is characterized by the use by pupils of the text as a background on which often there were unrelated to its content some unfold reflections: «I think about everything", "About the thoughts which have been arisen", "About yesterday", "About me, read more or not», "Who of my friends read this novel?». Although these answers include adolescents' self-appeal, personal orientations, they lack the necessary conditions to understand the novel of the separation of the positions of the subjects of literary communication, which is a condition for reaching a higher level of understanding the content of a novel. These answers characterize the low level of formation of adolescents as subjects of cognitive activity in experimental and control groups before the start of our author's experimental learning.

In the presence of different degrees of the expression of results according to each of these two trends in the experimental and control forms (see Table 1), there were clearly expressed common to all groups some increase in data according to the second trend.

Table 1

The results of adequate and inadequate trends in the communication of pupils of experimental and control forms with literature (in \%) (ascertaining experiment)

\begin{tabular}{|l|c|c|c|c|c|c|c|c|}
\hline \multirow{2}{*}{ The trend } & \multicolumn{4}{|c|}{$2019-2020$} & \multicolumn{4}{c|}{ 2020-2021 } \\
\cline { 2 - 9 } & E1 & E2 & C1 & C2 & E1 & E2 & C1 & C2 \\
\hline Adequate & 33.8 & 32.5 & 27.6 & 46.1 & 34.4 & 44.7 & 33.9 & 38.0 \\
\hline Inadequate & 45.3 & 76.7 & 54.0 & 61.5 & 71.2 & 62.1 & 51.0 & 49.9 \\
\hline
\end{tabular}

(C) Ternovyk Nataliia, Simko Alla

DOI (article): https://doi.org/10.32626/2227-6246.2021-52.253-274 
A comparison of the table data with pupils' answers to the questionnaire about the reasons for their misunderstanding of classical literature suggests that the growth of «inadequate" tendency in the perception of novels by adolescents is a natural process and it is due to the assimilation of stereotypes in their social environment as modern and not useful.

This is also evidenced by the growing percentage of answers to this question, such as: "I do not know why you need to read classical fiction at all», "I consider classical fiction unnecessary for a contemporary man», "I do not want to waste time understanding novels». Practically both in the tendencies, and in degrees of their expression there is no essential difference in control and experimental classes.

Thus, when we tell about a high level of understanding novels by the teens, we have to emphasize that pupils tried to analyze linguistic means of reflecting the individual style of the author. We'll give the examples from the lesson of Foreign Literature, where pupils discussed the novel «The Seagull» by R. Bach.

A pupil Nina S. from the form E1: «R. Bach's philosophical tale "The Seagull» is an allegorical story in which the author, through a realistic depiction of the land, a sea and a sky, the flight of seagulls, managed to give stories about an unusual seagull of amazing authenticity. It seems that an inner voice told it to Richard Bach, and the author only conveyed in words the strange duality of impressions, on the verge of possible and impossible, which seems to exist in the "psychology" of birds.

The novel corresponds to the definition of a parable, it is a short story that contains a message of moral or religious content and draws parallels with well-known things. The plot of the novel has a gospel structure: exile, death and resurrection, sermon, miracles and apostles. The author's conscious modification of the plot is also obvious, which consists in depicting the removal by transferring it to another, already allegorical, reality.

C Ternovyk Nataliia, Simko Alla

DOI (article): https://doi.org/10.32626/2227-6246.2021-52.253-274 
DOI: https://doi.org/10.32626/2227-6246.2021-52

2021. випУСК 52

The first and the second techniques, that is, the imitation of gospel motifs and their modifications, show the commonality of the only genre and the material of the story "The Seagull» with a much wider range of phenomena called the neo-romantic wave. The delineation of the traditional gospel myth, renewed and somewhat corrected in the history of the unusual seagull, which tries to overcome time, space and death through improvement, is not the only one.

All the novels of $\mathrm{R}$. Bach are characterized by metaphysical philosophy. The author defends the idea that our existence is not limited to space and time, we are not even born and die, but come to this world to enjoy the joy of self-improvement, to share experiences with those people or animals who care about us, to learn to love and forgive.

The story «The Seagull» depicts three stages in the formation of a seagull's personality: exile, which was the impetus for self-improvement, the importance of experience gained in constant training, and transfer to another reality, such as resurrection. There is also a pattern that for a more effective and expressive depiction of the reality is in the novel, the author uses the antithesis, the opposition of concepts. The antithesis reveals the main conflicts of the novel and helps the readers to form their own thoughts about what was happening:

"But way off alone, out by himself beyond boat and shore, Jonathan Livingston Seagull was practicing» (Bach, 2003: 7);

"...till the crowd of a thousand seagulls came to dodge and fight for bits of food» (Bach, 2003: 7).

When seagulls from Jonathan Livingston's entourage tried to find food, the Seagull learned to fly alone, like no other bird in a flock of seagulls. It is this episode that begins the story of the adventures of a seagull, who saw the purpose of life in something greater than just getting food. The author reveals to the reader the essence of the conflict that unfolds throughout the story, from the early beginning:

C Ternovyk Nataliia, Simko Alla

DOI (article): https://doi.org/10.32626/2227-6246.2021-52.253-274 
DOI: https://doi.org/10.32626/2227-6246.2021-52

2021. ВипУСК 52

"Most gulls don't bother to learn more than the simplest facts of flight - how to get from shore to food and back again. For most gulls, it is not flying that matters, but eating. For this gull, though, it was not eating that mattered, but flight. More than anything else, Jonathan Livingston Seagull loved to fly» (Bach, 2003: 10).

Also we've to show the monologue speech of another pupil, Petro V., from the form C1: "The seagull's distance from the flock was due to the peculiarity of his worldview. Jonathan's beliefs contradicted the opinion of the majority, even though the general opinion was still wrong. The typicality of such a situation can be traced during the confrontation of the individual and the society with established norms and rules. The situational allegory of the parable allows the reader to draw conclusions while reading and perceiving the value concepts depicted by the author.

Still remaining a part of the whole flock, the seagull is already formed as a free, intelligent individual. By perfecting the technique of his flights, Jonathan learns to understand the meaning of life, which must also be perfect. In heaven he attains perfect speed, love, honesty, freedom, wisdom, truth, self-respect and beauty. These concepts, together with such categories as time and knowledge, accumulate the energy of the activity, combining in the end into a single whole:

"But the speed was power, and the speed was joy, and the speed was pure beauty" (Bach, 2003: 17);

«The only true law is that, which leads to freedom» (Bach, 2003: 55);

"You have to practice and see the real gull, the good in every one of them, and to help them see it in themselves. That's what I mean by love» (Bach, 2003: 61).

In such a way we have to note that all levels of the Subject's positions are concentrated in one person. Also we assume that depending on pupils' activity, the individual manifests

(C) Ternovyk Nataliia, Simko Alla

DOI (article): https://doi.org/10.32626/2227-6246.2021-52.253-274 
DOI: https://doi.org/10.32626/2227-6246.2021-52

2021. випуск 52

himself / herself functionally at one level or another one by his / her own subjectivity, remaining structurally at a certain level of spirituality.

Subjectivity as a tendency to reproduce, to create oneself in appropriate and sometimes unfavorable conditions, is a universal characteristic of a person. Man's own activity is qualitatively transformed at each stage of ontogenesis, its role in mental development increases at the time of mental generation. Subjectivity does not arise suddenly and is not introduced from the outside, it is a genetic consequence of the transformation of lower forms into higher ones due to the self-development of the subjective principle of a person who actively interacts with the outside world. In this case, the social environment of the individual as a subject of activity plays an adequate role of external factors, conditions, but not determinants, which do not cause a mental development of the Subject.

\section{Conclusions}

Thus, the subject of mental activity can be considered as the individual if the object for him / her is his / her own psyche in its functioning and development; the regulation of the development processes is carried out by the Subject himself / herself, and not by any external forces, both on the conscious and unconscious levels (in the direction from what is not realized to what is increasingly realized with the transition of learned forms of self-regulation to subconscious levels). The Subject of mental activity provides individual acts only by the conditions of the development of own Subjective structures and building of the corresponding potentialities. In such a way, we think, that mature subject of mental activity will be characterized by such needs and abilities:

1) «goal-setting» of pupils' mental self-development as a regulators of this process;

2) providing «choice», «finding», «production» of psychological means which are necessary to achieve this goal;

C Ternovyk Nataliia, Simko Alla

DOI (article): https://doi.org/10.32626/2227-6246.2021-52.253-274 
DOI: https://doi.org/10.32626/2227-6246.2021-52

2021. ВИПУСК 52

3) «decision-making» about when and under what conditions the goal can be achieved by selected means to the maximum extent;

4) the implementation of decisions;

5) the "evaluation" of the results of implementation, the analysis of the causes of success and failure;

6) the "accumulation" of individual experience, the «fixation" of results and ways of the development of the psyche and the Subjective qualities of the person.

\section{Literature}

Abrams, D., \& Hogg, M. (1999). Social Identity and Social Cognition. Oxford. $350 \mathrm{p}$.

Adler, A., Lindzey, G., \& Hall, C. (1997). Individual Psychology. Theories of Personality. New York : New York Wiley. P. 114-156.

Bach, R. Jonathan Livingston Seagull. Москва : Айрис Пресс, 2003. $103 \mathrm{c}$.

Beauvillain, C. (1994). Morphological structure in visual word recognition: Evidence from prefixed and suffixed words. Language and Cognitive Processes. Vol. 9 (3). P. 317-339.

Bennett, M. (1998). Basic concepts of Intercultural Communication: Selected Readings. Yarmouth. $232 \mathrm{p}$.

Brédart, S. (1991). Word interruption in self-repairing. Journal of Psycholinguistic Research. Vol. 20. P. 123-137. URL : https://doi.org/ $10.1007 /$ bf01067879.

Dubovyk, S. H., Mytnyk, A. Ya., Mykhalchuk, N. O., Ivashkevych, E. E., \& Khupavtseva, N. O. (2020). Preparing Future Teachers for the Development of Students' Emotional Intelligence. Journal of Intellectual Disability - Diagnosis and Treatment. Vol. 8. No. 3. P. 430-436. URL : https://www.lifescienceglobal.com/journals/ journal-of-intellectual-disability-diagnosis-and-treatment/volume8-number-3/82-abstract/jiddt/4038-abstract-preparing-futureteachers-for-the-development-of-students-emotional-intelligence. DOI https://doi.org/10.6000/2292-2598.2020.08.03.20.

Mykhalchuk, Nataliia, \& Kryshevych, Olga. The peculiarities of the perception and understanding of Sonnets written by W. Shakespeare by the students of the Faculty of Foreign Languages. Psycholinguistics. Психолінгвістика. Психолингвистика: Збірник наукових праць. Серія: Психологія. Переяслав-Хмельницький : ФОП Дом-

(C) Ternovyk Nataliia, Simko Alla

DOI (article): https://doi.org/10.32626/2227-6246.2021-52.253-274 
DOI: https://doi.org/10.32626/2227-6246.2021-52

2021. ВИПУСК 52

бровська Я. М., 2019. Вип. 26 (1). С. 265-285. DOI 10.31470/ 2309-1797-2019-26-1-265-285.

Onufriieva, L., Chaikovska, O., Kobets, O., Pavelkiv, R., \& Melnychuk, T. (2020). Social Intelligence as a Factor of Volunteer Activities by Future Medical Workers. Journal of History Culture and Art Research. Vol. 9. No. 1. P. 84-95. DOI http://dx.doi.org/ 10.7596/ taksad.v9i1.2536. URL : http://apps.webofknowledge.com/full_ record.do? product $=$ WOS\&search_mode $=$ GeneralSearch\&qid $=3 \&$ $\mathrm{SID}=\mathrm{C} 2$ rooGzb9Eyq41CkoTY\&page $=1 \&$ doc $=1$.

Vovk, M., Emishyants, O., Zelenko, O., Drobot, O., \& Onufriieva, L. (2020). Psychological Features of Experiences of Frustration Situations in Youth Age. International Journal of Scientific \& Technology Research. Vol. 8. Issue 01. P. 920-924. URL : http://www.ijstr.org/ paper-references.php?ref=IJSTR-0120-28117.

\section{References}

Abrams, D., \& Hogg, M. (1999). Social Identity and Social Cognition. Oxford.

Adler, A., Lindzey, G., \& Hall, C. (1997). Individual Psychology. Theories of Personality, (pp. 114-156). New York : New York Wiley.

Bach, R. (2003). Jonathan Livingston Seagull. Moscow : Iris Press.

Beauvillain, C. (1994). Morphological structure in visual word recognition: Evidence from prefixed and suffixed words. Language and Cognitive Processes, 9 (3), 317-339.

Bennett, M. (1998). Basic concepts of Intercultural Communication: Selected Readings. Yarmouth.

Brédart, S. (1991). Word interruption in self-repairing. Journal of Psycholinguistic Research., 20, 123-137. Retrieved from https://doi.org/ $10.1007 / \mathrm{bf} 01067879$.

Dubovyk, S. H., Mytnyk, A. Ya., Mykhalchuk, N. O., Ivashkevych, E. E., \& Khupavtseva, N. O. (2020). Preparing Future Teachers for the Development of Students' Emotional Intelligence. Journal of Intellectual Disability - Diagnosis and Treatment, 8 (3), 430-436. Retrieved from https://www.lifescienceglobal.com/journals/journal-of-intellectualdisability-diagnosis-and-treatment/volume-8-number-3/82abstract/jiddt/4038-abstract-preparing-future-teachers-for-thedevelopment-of-students-emotional-intelligence. DOI https://doi. org/10.6000/2292-2598.2020. 08.03.20.

Mykhalchuk, Nataliia, \& Kryshevych, Olga (2019). The peculiarities of the perception and understanding of Sonnets written by W. Shakespeare by the students of the Faculty of Foreign Languages. Psycholinguis-

(C) Ternovyk Nataliia, Simko Alla

DOI (article): https://doi.org/10.32626/2227-6246.2021-52.253-274 
DOI: https://doi.org/10.32626/2227-6246.2021-52 2021. ВИПУСК 52

tics. Psykholinhvistyka. Psikholingvistika - Psycholinguistics. Psycholinguistics. Psycholinguistics, 26 (1), 265-285. Pereiaslav-Khmelnytskyi : FOP Dombrovska Ya. M. DOI 10.31470/2309-1797-201926-1-265-285.

Onufriieva, L., Chaikovska, O., Kobets, O., Pavelkiv, R., \& Melnychuk, T. (2020). Social Intelligence as a Factor of Volunteer Activities by Future Medical Workers. Journal of History Culture and Art Research, 9 (1), 84-95. DOI http://dx.doi.org/10.7596/taksad.v9i1.2536. Retrieved from http://apps.webofknowledge.com/full_record.do? product $=$ WOS\&search $\_$mode $=$GeneralSearch $\& q i d=3 \& S I D=C 2$ rooGz b9Eyq4lCkoTY\&page $=1 \&$ doc $=1$.

Vovk, M., Emishyants, O., Zelenko, O., Drobot, O., \& Onufriieva, L. (2020). Psychological Features of Experiences of Frustration Situations in Youth Age. International Journal of Scientific \& Technology Research, 8 (01), 920-924. Retrieved from http://www.ijstr.org/paperreferences.php?ref=IJSTR-0120-28117.

Терновик Наталія, Сімко Алла. Психологічний зміст проблеми формування учнів як суб'єктів учіння

\section{АНОТАЦІЯ}

Метою дослідження $\epsilon$ проведення експерименту в закладі загальної освіти з метою встановлення ступеня розвитку учнів як Суб'єктів пізнавальної діяльності на основі аналізу змісту внутрішнього спілкування школярів і їх квазіспілкування з романами на різних етапах розуміння їхнього змісту в ситуаціях розв'язання дискурсивних творчих завдань у різноманітному літературному й особистісному середовищі.

Для розв'язання поставлених у роботі завдань використано такі теоретичні методи дослідження: категоріальний, структурно-функціональний, аналіз, систематизація, моделювання, узагальнення. У якості експериментального методу використано авторську анкету "Анкета для школярів».

Результати дослідження. Доведено, що всі рівні позицій суб'єкта концентруються в одному діючому індивіді. Обгрунтовано, що залежно від своєї активності індивід виявляє себе функціонально на одному чи іншому рівні суб'єктності, залишаючись структурно на певному рівні духовності.

Показано, що суб'єктність як схильність до відтворення, творення себе у відповідних, а часом і в несприятливих умовах, є універсальною

(C) Ternovyk Nataliia, Simko Alla DOI (article): https://doi.org/10.32626/2227-6246.2021-52.253-274 
властивістю живої матерії. Власна активність людини якісно перетворюється на кожному етапі онтогенезу, їі роль у психічному розвитку зростає в моменти породження психічного змісту. Суб'єктність не виникає раптово і не привноситься ззовні, вона є генетичним наслідком трансформації нижчих форм у вищі завдяки саморозвитку суб'єктного початку в людині, яка активно взаємодіє із зовнішнім світом. При цьому соціальне оточення індивіда як суб'єкта активності відіграє адекватну йому роль зовнішніх чинників, умов, але не детермінант, не причин психічного розвитку тощо.

Висновки. Отже, суб'єктом психічної активності індивід може вважатися в тому випадку, якщо об'єктом для нього постає його власна психіка в її функціонуванні й розвитку; регуляцію процесів розвитку здійснює сам суб'єкт, а не будь-які зовнішні сили, причому як на свідомому, так і на неусвідомлюваному рівнях (в напрямку від того, що не усвідомлюється, до того, що все більшою мірою усвідомлюється з переходом опанованих форм саморегулювання на підсвідомі рівні). Суб'єктом психічної активності індивід може поставати лише за умов розвитку власних суб'єктних структур і нарощування відповідних потенцій. Доведено, що зрілого суб'єкта психічної активності характеризують його потреби $і$ здатності до: 1) "цілепокладання» свого психічного розвитку і себе як регулятора цього процесу; 2) "вибору», "знаходження», "продукування» психологічних засобів, необхідних для досягнення поставленої мети; 3) «прийняття рішень» щодо того, коли і за яких умов поставлена мета може бути досягнута обраними засобами максимальною мірою; 4) виконання прийнятих рішень; 5) «оцінки» результатів виконання, аналізу причин успіху-неуспіху; 6) «накопичення» індивідуального досвіду, «ріксачії» результатів і способів розвитку своєї психіки і своїх суб'єктних якостей.

Ключові слова: Суб'єкт, суб'єктність, розуміння романів, певний рівень духовності, «оцінка» результатів виконання, «накопичення» індивідуального досвіду.

Терновик Наталия, Симко Алла. Психологическое содержание проблемы формирования учащихся как субъектов учения

\section{АНнОтАЦИЯ}

Целью исследования является проведение эксперимента в общеобразовательной средней школе с целью установления степени развития уча(c) Ternovyk Nataliia, Simko Alla

DOI (article): https://doi.org/10.32626/2227-6246.2021-52.253-274 http://journals.uran.ua/index.php/2227-6246 
щихся как Субъектов познавательной деятельности на основе анализа содержания внутреннего общения школьников и их квазиобщения с романами на разных этапах понимания содержания последних в ситуациях решения дискурсивных творческих задач в широкой литературной и личностно значимой среде.

Для решения поставленных в работе задач использованы следующие теоретические методы исследования: категориальный, структурно-функциональный, анализ, систематизация, моделирование, обобщение. В качестве экспериментального метода использована авторская анкета «Анкета для школьников».

Результаты исследования. Доказано, что все уровни позиций субъекта концентрируются в одном действующем индивиде. Обосновано, что в зависимости от своей активности индивид проявляет себя функционально на одном или другом уровне субъектности, оставаясь структурно на определенном уровне духовности.

Показано, что субъектность как склонность к воспроизводству, созданию себя в соответствующих, а порой - и в неблагоприятных условиях, является универсальным свойством живой материи. Собственная активность человека качественно превращается на каждом этапе онтогенеза, ее роль в психическом развитии возрастает в моменты порождения психического содержания. Субъектность не возникает внезапно и не привносится извне, она является генетическим следствием трансформации низших форм в высшие благодаря саморазвитию субъектного начала в человеке, который активно взаимодействует с внешним миром. При этом социальное окружение индивида как субъекта активности играет адекватную роль внешних факторов, условий, но не детерминант, не причин психического развития личности.

Выводы. Таким образом, субъектом психической активности индивид может считаться в том случае, если объектом для него является его собственная психика в ее функционировании и развитии; регуляцию процессов развития осуществляет сам субъект, а не какие-либо внешние силы, причем как на сознательном, так и на неосознаваемом уровнях (в направлении от того, что не осознается, к тому, что все в большей степени осознается с переходом освоенных форм саморегулирования на подсознательном уровне). Субъектом психической активности индивид может быть лишь при условии развития собственных субъектных структур и наращивания соответствующих потенциалов. Доказано,

(C) Ternovyk Nataliia, Simko Alla DOI (article): https://doi.org/10.32626/2227-6246.2021-52.253-274 
DOI: https://doi.org/10.32626/2227-6246.2021-52

2021. ВИПУСК 52

что зрелого субъекта психической активности характеризуют его потребности и способности к: 1) "целеполаганию» своего психического развития и себя как регулятора этого процесса; 2) "выбору», "нахождению», "воспроизводству» психологических средств, необходимых для достижения поставленной цели; 3) «принятию решений» относительно того, когда и при каких условиях поставленная цель может быть достигнута избранными средствами в максимальной степени; 4) выполнению принятых решений; 5) "оценке» результатов выполнения, анализа причин успеха-неуспеха; 6) «накоплению» индивидуального опыта, "фиксации» результатов и способов развития своей психики и своих субъектных качеств.

Ключевые слова: Субъект, субъектность, понимание романов, определенный уровень духовности, «оценка» результатов выполнения, «накопление» индивидуального опыта.

Original manuscript received March 04, 2021 Revised manuscript accepted April 14, 2021

(C) Ternovyk Nataliia, Simko Alla

DOI (article): https://doi.org/10.32626/2227-6246.2021-52.253-274 http://journals.uran.ua/index.php/2227-6246 